\title{
Material Methods; Considering Ceramic Raw Materials and the Spread of the Potter's Wheel in Early Iron Age Southern Iberia
}

\author{
Beatrijs G. de Groot ${ }^{1 *}$ \\ ${ }^{I}$ The University of Edinburgh, School of History, Classics and Archaeology, William Robertson Wing, Old Medical School, Teviot Place, Edinburgh, \\ EH8 $9 A G$, United Kingdom
}

\section{A RTICLE INFO}

\section{Article history:}

Received: $22^{\text {th }}$ February 2021

Accepted: $24^{\text {th }}$ October 2021

DOI: http://dx.doi.org/10.24916/iansa.2021.2.16

\section{Key words:}

Iberian Peninsula

Iron Age

ceramic raw materials

Phoenicians

potter's wheel

technology

hybridity

\begin{abstract}
A B S TR A C T
This paper discusses the role of clay selection and preparation in the production of wheel-made pottery in Early Iron Age southern Iberia. The first systematic use of potter's wheels in the production of Early Iron Age ceramics in southern Iberia corresponds to the establishment of pottery workshops associated with Phoenician trade colonies, dating to the period between the end of the $10^{\text {th }}$ and $7^{\text {th }}$ century BCE. There are still many gaps in our understanding of how technological knowledge was transmitted between the Phoenician workshops and “indigenous' communities that adopted the potter's wheel. This paper draws upon a growing body of archaeometric and ceramic technological research to consider clay selection strategies in these new workshops. Secondly, this paper will consider the role of ceramic raw materials in the development of new "hybrid' ceramic forms, particularly grey-ware. It will hereby provide theoretical considerations surrounding the significance of material cultural hybridity in answering questions raised by postcolonial archaeologists about identity, cultural transmission and hybridisation in the context of the Phoenician colonial system.
\end{abstract}

\section{Introduction}

In the Iberian Peninsula, the first millennium BCE is a period of socio-economic and cultural transformations, which culminated in the development of proto-urban lifeways (Almagro Gorbea, 2014). Widespread changes took place in the organisation of food production and consumption, religious practices, pottery technology and metallurgy. Fundamental to the changes taking place here were the expansion of Phoenician long-distance trade networks, which facilitated the spread of people and technological innovations across the Mediterranean (e.g., Manning, 2018, p.38). In the Iberian Peninsula, Phoenician groups settled in trade colonies on the southern coastline in the $9^{\text {th }}$ century BCE, utilising rural hinterlands for farming and extracting Mineral ores from the interior mountain ranges (Aubet Semmler, 2008; Dietler and López-Ruiz, 2009). The processes of dissemination of elements

*Corresponding author. E-mail: Beatrijs.de.Groot@ed.ac.uk from a Mediterranean koine developed into the eclectic "orientalising" material culture styles of the southern Iberian Iron Age (Celestino Pérez and López-Ruiz, 2016).

In and around these Phoenician colonies, workshops appeared that utilised the potter's wheel and doublechambered updraught kilns to produce vast quantities of luxury tableware as well as containers for trade goods (Mielke and Torres Ortiz, 2012; Mielke, 2015). In the centuries that followed, the production of wheel-made pottery expanded across the Iberian Peninsula, outside of context of the Phoenician colonial system (Ramón Torres et al., 2007; Delgado Hervás, 2011; García Vargas and García Fernández, 2012; Fernández Maroto, 2013; Jiménez Avila, 2013; Mielke and Torres Ortiz, 2012; Sáez Romero et al., 2021). Despite strong evidence for the growing production and use of wheel-made pottery outside of the Phoenician colonies, particularly after the $7^{\text {th }}$ century BCE (Coll Conesa, 2000), there are still many gaps in our knowledge of the process by which this workshop mode of production developed, how it 
spread and how its adoption affected existing craft traditions in the Iberian Peninsula. ${ }^{1}$

This paper focuses on a specific area of the chaine opératoire of early wheel-made pottery; the selection and preparation of clays, in order to address questions surrounding the development of knowledge about suitable clay and temper recipes for the production of wheel-made pottery. Recent research has provided detailed insights into the production process, or chaîne opératoire, of ceramics produced in the Phoenician-tradition workshops (Sáez Romero et al., 2021), evidence which is important for reconstructing the spread of technological information relating to ceramic production across southern Iberia. By comparing data from a growing body of archaeometric research, this paper draws out some general conclusions surrounding the way in which the new pottery workshops built upon, or replaced, traditional knowledge about clay recipes. Particular attention will be paid to the premise, informed by ethnoarchaeological literature, that clay selection and preparation are often a cultural "choice", rather than an economic or environmentally determined solution. This paper addresses the different factors that might influence clay selection strategies for the production of wheel-made pottery in the context of Iron Age southern Iberia, investigating the opposition between economic and cultural preferences.

To address the above aims, this paper also integrates information about the procurement and preparation of ceramic raw materials into broader philosophical questions surrounding the adoption and rejection of new technologies in Iron Age Iberia. In order to do so it focuses on the development of grey-ware, a class of ceramics that might have developed as a "hybrid" form, imitating handmade "indigenous" pottery but produced on the potter's wheel, a technology associated with the Phoenicians. The significance of this type of material is analysed by focusing on evidence for the origin of its ceramic raw materials to understand the mixing of technological knowledge and visual style more fully.

I take the regions of southern Iberia near the Phoenician colonies as my primary case-study because "orientalising" material culture and technology has been strongly influential in this area (omitting Extremadura due to a lack of published archaeometric studies on early wheel-made pottery in this region). This includes the "Tartessian" area, the area of present-day Andalucía, as well as Southern Portugal and Lisbon. The time-period discussed is restricted to the first appearance of Phoenician settlements to the period immediately after the so-called "crisis" in the mid- $6^{\text {th }}$ century BCE.

\footnotetext{
1 The complexity of the processes of interaction underpinning the spread of potter's wheels is emphasised by the suggestion that rotational devices were used from the Final Bronze Age onwards in Central Iberia at El Castro de Cogotas during the 9th to 7th century BCE (Padilla-Fernández, 2019).
}

\section{Clay selection and preparation; cultural or economic choice?}

With the growing importance of post-processual frameworks in archaeology, the development of archaeological thought about the use of raw materials has shifted from a focus on functional properties to culturally informed, transmitted knowledge. Instead of striving for a "best way" in the development of technological practices, research into the chaîne opératoire of ceramic production demonstrates that there are numerous equivalent methods to produce ceramics (e.g., Dobres, 1999; Roux, 2019) and that such variation can reflect the technological styles (e.g., Lechtman, 1977) of different social groups. Technological variation can therefore be used to explore questions of cultural transmission and agency (e.g., Pauketat, 2001).

In the context of raw material selection and preparation, the earliest steps in the chaine opératoire of ceramic production, ethnographic studies demonstrate that technological practices might not be deliberately selected, as if choosing the appropriate tool or practice for the task at hand "from a catalogue" (Gosselain, 1992). Instead, the composition of ceramic pastes can reflect the preferences and material knowledge of potters, which are shaped by sociallytransmitted conventions (e.g., Gosselain, 1992; Livingstone Smith, 2000; Pauketat, 2001). Spatio-temporal patterns in the similarity of clay recipes can therefore provide insights into the strategies of - and relationships between - contemporary potting traditions, as well as informing a discussion on the long-term development of material knowledge.

Although socially-transmitted information in theory provides an important determining factor in the selection of clay and temper, potters establishing the first workshops in the Iberian Peninsula will have had to take a number of factors into account. Such workshops will have been part of the Phoenician commercial economy, in which ceramic production ran parallel to other industries to facilitate the production and long-distance trade of goods (see below). The choice of clay and temper formed part of a wide set of demands, such as the proximity of pottery workshops to transport routes and food production sites, which will have affected the choice of raw material source next to personal preference or social conventions. Furthermore, wheel-thrown pottery is generally produced from clay with fine-grained non-plastic inclusions to avoid abrasion of the potter's hands (Rice, 2015, p.143) or marring and tearing of the pot surface (Sinopoli, 1991, p.101), suggesting that the properties of clays deserve attention in explaining selection.

As such, it is important to assess how innovations act as "systems" of related technological choices, raw materials, logistics and economic contexts (e.g., Sillar and Tite, 2000). By providing empirical evidence of continuity or the changes in raw material selection co-occurring with the introduction of the potter's wheel, mineralogical and archaeometric studies can contribute to understanding the workings of changes in such technological systems. By focussing on the materials from which ceramics were made, it is possible to gain 
insights into processes of communication of environmental knowledge and/or experimentation with new clay recipes and the cultural construction and use of the landscape (e.g., Albero Santacreu, 2017), particularly concerning the location of suitable clay sources and clay procurement strategies. Below I will integrate such information in a broader discussion on the development and spread of pottery production in Early Iron Age southern Iberia.

\section{Background: the economics of Phoenician pottery production}

In order to investigate the organisation of ceramic production in western Phoenician communities it is informative to consider the role of ceramic production in the wider Phoenician colonial system. Although the relation between the adoption of potter's wheels and mass-production is rarely straightforward (Roux and Courty, 1998; Baldi and Roux, 2016; Choleva, 2020)2, in the western Mediterranean

\footnotetext{
2 Roux and Courty (1998) distinguish the different shaping methods the potter's wheel affords, providing valuable insights into the utilisation of Rotational Kinetic Energy (RKE) next to combinations of hand-shaping and rotation. Although comprehensive studies of the shaping methods employed in the production of Phoenician pottery in the Iberian Peninsula
}

the introduction of this technology corresponds closely to the intensification of ceramic production for long-distance trade. The production of storage containers and tableware in this region was initially part of the commercial strategy of Phoenician colonies, whose economy focussed on the maritime trade of agricultural surplus and luxury goods. Phoenician pottery of local manufacture was found at Huelva (Figure 1) in layers dating to at least 900 BCE (Millán et al., 1990; Nijboer and van der Plicht, 2006; Delgado Hervás, 2011, pp.11-12; González de Canales et al., 2017). Evidence for the local production of Phoenician-type wheel-made pottery indicates that eastern Mediterranean(-trained) potters were quick to instate a local pottery industry after settlement in the Iberian Peninsula (Millán et al., 1990), which will have involved the use of double-chambered updraught kilns as well as the use of low potter's wheels or stick wheels (e.g., Jiménez Avila, 2013). The earliest excavated ceramic workshops in Phoenician centres at Málaga and Toscanos date to the $7^{\text {th }}$ century BCE (Curià Barnès et al.,

are rare, some evidence demonstrates that such pottery was produced through different shaping technologies including wheel-throwing and wheel-coiling (Dorado Alejos, 2019). Hand-shaping methods prevailed in the Iberian Peninsula during the Late Bronze Age, with pinching, coiling and slab-building recorded for assemblages across the Iberian South-East (e.g., Dorado Alejos, 2019).

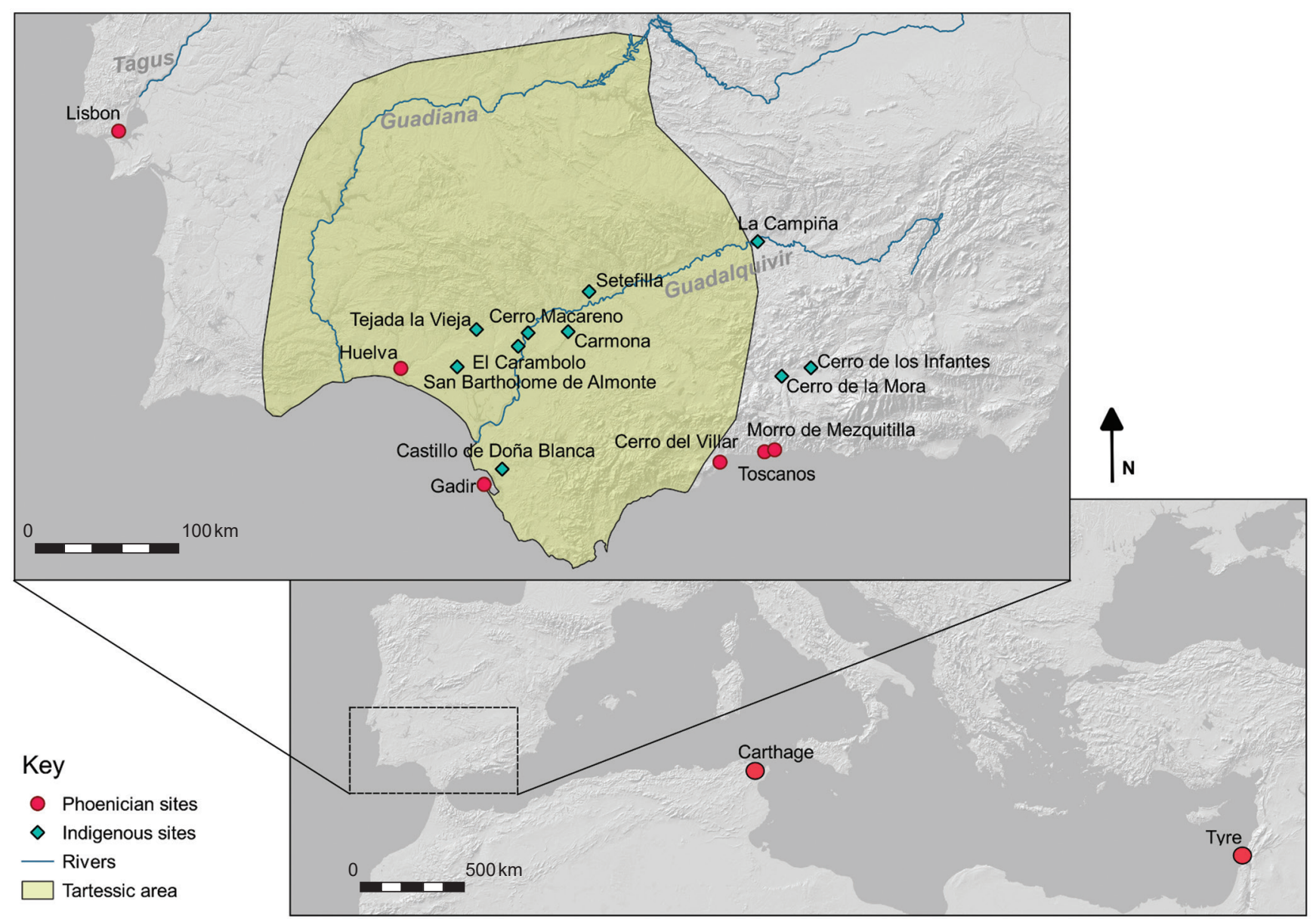

Figure 1. Map of sites with published archaeometric data on Early Iron Age pottery. The shaded area marks the outline of the area of influence of Tartessos (after Celestino Pérez and López-Ruiz, 2016, p.175). 
2000; Arancibia-Román and Escalante Aguilar, 2006; García Vargas and García Fernández, 2012; Mielke and Torres Ortiz, 2012, p.279). Evidence of ceramic manufacture in and nearby other Phoenician sites dating to the same period also derives from the distribution of ceramic prisms, which were used to separate pottery during firing within the kiln and are highly diagnostic (Delgado Hervás, 2011; Gutiérrez López et al., 2013). During this period, next to the production of Phoenician-type ceramics, there is also evidence for the local production of ceramics of Greek typology at Huelva (González de Canales et al., 2018) as well as the development of "hybrid" ceramic forms such as grey-ware (explored further below), pointing to the heterogeneous influences affecting wheel-made pottery production in southern Iberia.

Phoenician workshops such as Cerro del Villar produced symmetrical and standardised storage vessels (amphorae, pithoi, globular pots and bottles), tableware (plates, carinated bowls, dishes, jars and cups) and vessels destined for other uses (pots, urns, tripods) (Curià Barnès et al., 2000, p.1475). Archaeometric studies confirm that such ceramics circulated widely in the western Mediterranean (Behrendt and Mielke, 2011; Miguel Gascón et al., 2015) as well as reaching more distant places in the eastern Mediterranean (Fantuzzi et al., 2020). One of the largest and most comprehensive of such studies on the provenance of early wheel-made pottery in the Iberian Peninsula is the Instrumental Neutron Activation Analysis (INAA) research conducted by Sonja Behrendt (Behrendt and Mielke, 2011). Chemical signatures from 224 Phoenician wheel-made ceramic samples were obtained from vessels deriving from nineteen Early Iron Age Phoenician sites in the southern half of the Iberian Peninsula and northern Morocco. The results show that wheel-made pottery circulated around four main production centres associated with workshops in Phoenician settlements (Behrendt and Mielke, 2011, p.193). Phoenician ceramics from production centres located around the Straits of Gibraltar, Sicily and Carthage appear in Early Iron Age contexts in north-eastern Iberia (Miguel Gascón et al., 2015) and the Atlantic coast of Iberia (González-Ruibal, 2004; de Sousa, 2019), suggesting that the Phoenician colonies controlled trade with indigenous Iberian communities as intermediaries through a so-called cabotage system (Rafel Fontanals, 2012).

The potter's wheel was an integral part of the process of containerisation and wider economic opportunities regarding the speed and quantity of production, (Bevan, 2014, p.392) standardisation and the generation/exploitation of new markets. The economic character of early workshops employing the potter's wheel is reflected by the location of pottery workshops, which overlapped with that of the production of agricultural trade goods (Bernal Casasola and Sáez Romero, 2003). Industrial landscapes marked by the convergence of pottery production and salted-fish processing for trade seem to have emerged soon after the emergence of Phoenician settlements and flourished in the Punic period (c. after 550 BCE) (Sáez Romero, 2008; Carretero, 2007; Sáez Romero, 2014). Through connecting such industrial landscapes to the wider Mediterranean, the exchange in foodstuffs and luxury tableware offered opportunities for generating wealth. The development and prevalence of "orientalising" objects in the Tartessian region (Figure 1) of the Iberian south demonstrates how, next to the inhabitants of the Phoenician colonies, segments of the broader population exploited such opportunities (Delgado Hervás, 2013).

\subsection{The inland spread of pottery workshops}

During the $7^{\text {th }}$ century BCE, workshops with Phoeniciantype kilns appear in the southern half of the Iberian Peninsula, in "indigenous" settlements such as Cerro de los Infantes (Mendoza et al., 1981; Mielke, 2015; García Vargas and García Fernández, 2012), Cerro de la Mora (Carrasco et al., 1985) and La Campiña (Molinos et al., 1994) (see also Sáez Romero et al., 2004; García Vargas and García Fernández, 2012). Workshop-based production of wheelmade amphorae and fine ware is also attested at number of different indigenous sites as indicated by archaeometric studies, as will be discussed further below. Such production centres, located outside of the immediate surroundings of the Phoenician colonies, demonstrate that local groups began to participate in the production of ceramics for regional and interregional trade. This process intensifies after the $6^{\text {th }}$ century BCE "crisis" (Escacena Carrasco, 1993), a period in which the Phoenician colonial system declined (e.g. Torres Ortiz, 2014, p.275). Petrographic and chemical analysis of amphorae dating to the $6^{\text {th }}-2^{\text {nd }}$ centuries BCE demonstrates that new workshops, located in the Guadalquivir Valley and the Tagus and Sado Valleys of Portugal, and the Iberian East coast, developed, gaining access to the commercial networks that were originally controlled by the Phoenician colonies (González Prats and Pina Gosálbez, 1983; Moreno Megías et al., 2020). This has provided evidence contributing to existing discussions about the relationship between coastal and inland economic systems during this period. After the $6^{\text {th }} \mathrm{c}$. BCE, amphorae were used for the transport of wine as indicated by residue analysis (Petit-Domínguez et al., 2003), and a range of other products such as olive oil, fish by-products, honey, meat preserves and milk by-products (Carretero et al., 2008; García Fernández et al., 2016). During this period, we also find the development of ceramic industries associated with the Central and Northern Iberian oppida, forming a new and highly decorative style of locally-produced, wheelmade ceramics (Lorrio, 2014).

This general overview suggests that commerce was an important driver for the initial spread of the potter's wheel in southern Iberia. The production of ceramic transport containers and luxury commodities at different centres on the Iberian south coast indicate that a significant level of standardisation existed, allowing these different centres to produce in-demand commodities for local and distant markets. The next section will examine if such standardisation is also reflected in choices potters made in selecting clay and temper. 


\section{Clay provenance and preparation in Early Iron Age southern Iberia}

A growing body of archaeometric work has provided evidence for petrographic and chemical groupings in Phoenician pottery from the western Mediterranean (e.g., Arribas et al., 1989; Millán et al., 1990; Amadori and Fabbri, 1998; Pringle, 1998; Cardell et al., 1999; Edreira et al., 2001; Ruiz et al., 2006; Cau Ontiveros, 2007; Cau Ontiveros et al., 2010; Behrendt and Mielke, 2011; Miguel Gascón et al., 2015; Johnston, 2015; Ferreira et al., 2020). Such studies provide data concerning the variability of fabrics and origin of clay sources at individual sites, but they also reveal information on clay procurement and preparation strategies characterising western Phoenician ceramic production and how this compares to such technological habits in indigenous contexts. The review of a selection of this archaeometric research below provides an initial characterisation of the technological choices made by potters utilising potter's wheels in Early Iron Age southern Iberia (both in indigenous and Phoenician contexts). The aim of this is to provide a discussion as to whether these can be understood as part of a broader "technological style" or are informed by economic choices and environmental variation.

\subsection{Clay procurement}

A starting point for understanding clay selection preferences in the western Phoenician colonies is to compare the nature of the ceramic fabrics from different Phoenician and "indigenous" ceramic workshops and consider variation in the mechanical properties of ceramic raw materials. In order to situate Phoenician ceramic production in Iberia, it is useful to characterise clay procurement and preparation habits of other Phoenician settlements. For example, Phoenician ceramics from the necropolis of Tyre-al Bass, dating to $850-550 \mathrm{BCE}$, were produced from highly calcareous pastes (Miguel Gascón and Buxeda i Garrigós, 2013), while calcareous clays tempered with crushed calcite or sand were used in the production of wheel-made pottery at Carthage (Miguel Gascón et al., 2015). Phoenician pottery from Sardinia, instead, is often tempered with grog (Miguel Gascón et al., 2015), demonstrating that variation exists between clay preparation strategies in different Phoenician contexts. In the Iberian Peninsula, however, a preference for using calcareous clays or clays with a high calcite content in the production of Phoenician-type ceramics seems likely (Table 1). Calcareous clays were used in the production of wheel-made Phoenician pottery from Castillo de Doña Blanca, near the Phoenician colony of Gadir (Cau Ontiveros, 2007; Johnston, 2015; Fantuzzi et al., 2020, p.6) as well as at Huelva and São Jorge Castle in Lisbon (Ferreira et al., 2020). At the indigenous site of Cerro Macareno, wheel-made pottery is produced from calcareous clays, contrasting with handmade pottery, which is produced from metamorphic clays (González-Vilchez et al., 1982). Also at Setefilla (Bartkowiak and Krueger, 2015; Krueger et al., 2018; Krueger et al., 2021), there seems to have been a preference for using calcareous clay in the production of wheel-thrown pottery, although ferruginous clays were also often utilised (Krueger et al., 2018).

The advantageous properties of calcareous clays are that such clays sinter at lower temperatures, allowing for a less tight control over firing to obtain a suitable level of strength (Tite and Maniatis, 1975). Other mechanical properties of clays with a high calcite content include the way in which calcium affects the clay-water system, improving their toughness and workability (Hoard et al., 1995, p.265, Müller et al., 2014), properties that are useful for ensuring the structural integrity of vessels during shaping or throwing on the wheel. Whether the selection of clays was determined by such functional advantages is debatable, particularly because many different factors can contribute to the choice of clays (see Discussion). Furthermore, many other workshops utilised non-calcareous clays from nearby deposits for the production of wheel-made pottery (Fantuzzi et al., 2020, Amadori et al., 2017, Amadori and Fabbri, 1998, Ferreira et al., 2020, Ferreira et al., 2018). For example, late $8^{\text {th }}$ century and $7^{\text {th }}$ century BCE wheel-made pottery from Toscanos were produced using metamorphic clays while a second, calcareous fabric, corresponds to imports from Carthage (Amadori et al., 2017). Evidence for particular clay procurement strategies other than an opportunistic use of locally available resources is therefore currently limited, but future consideration of the mechanical differences in pottery clays for producing wheel-made pottery can be informative about the observed distinction between the raw materials used for the production of hand-made and wheelmade pottery.

\subsection{Clay preparation}

Ceramic petrography can provide insights into the use of temper, indicated by the angularity of inclusions, grain-size distribution (which should be bimodal if crushed rocks or sand is added as temper), and a difference in the minerals in coarse and fine fraction (Quinn, 2013). Nevertheless, it can often be challenging to confirm if mineral inclusions were added as temper or whether such inclusions were naturally present in the clay matrix. The reviewed literature demonstrates that we have limited conclusive evidence for the use of temper in the production of early wheel-made pottery in the Phoenician colonies. Non-plastics in the ceramic fabrics of wheel-made pottery often reflect minerals that could be present in clays naturally. The use of crushed calcite is suggested at a number of sites that are part of Behrendt and Mielke's (2011) study, although the authors are not explicit about the question of whether materials are added as temper (Behrendt and Mielke, 2011, pp.198-223). At Castilla de Doña Blanca there is one quartz-tempered fabric group (Johnston, 2015, p.253) among the wheel-made samples, but in other contexts the literature is inconclusive.

Wheel-made ceramics produced in indigenous contexts more often contain temper. For example, the use of mineral tempers seems to have been common in the production of Punic-Turdetanian amphorae during the $6^{\text {th }}-2^{\text {nd }}$ centuries 


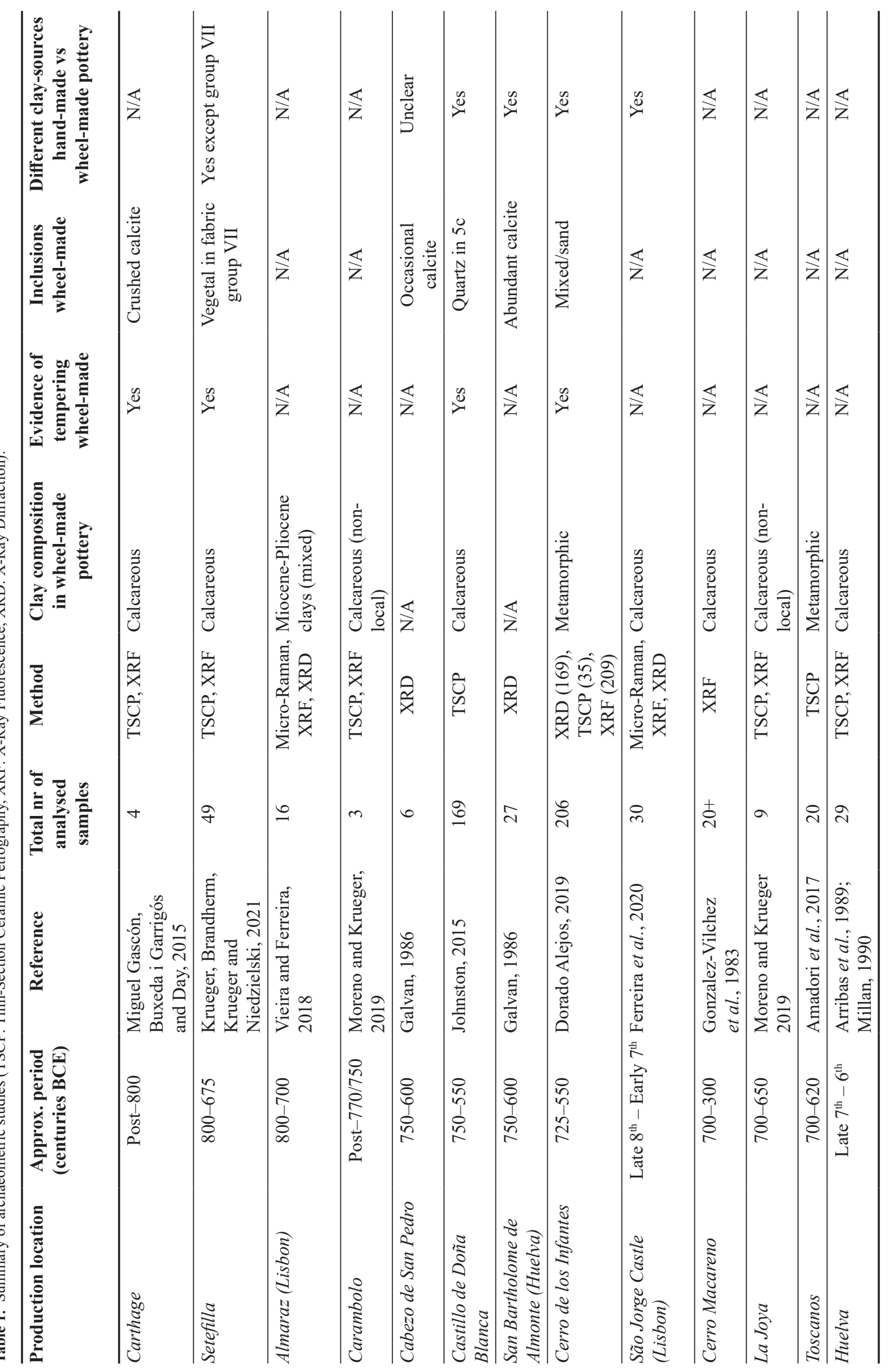


BCE (Moreno Megías et al., 2020, pp.6-10). At Setefilla, we find the presence of vegetal temper in wheel-made pottery, which also occurs in some hand-made vessels (Krueger et al., 2021). Based on the reviewed studies it therefore appears that there is little evidence for a set clay recipe in the production of early Iron Age wheel-made pottery in southern Iberia. However, future systematic and targeted comparative studies might be able to draw out regional or local similarities more clearly.

Instead of adding minerals as temper, it is likely that, instead, potters often removed larger minerals and other impurities. Fantuzzi et al.'s (2020) study of amphorae from different production centres on the southern Iberian coastline demonstrates that clay samples from around Phoenician settlements often contain larger mineral fragments than the clay fabrics analysed, suggesting that such clays might not have been used in a raw state, but rather were processed prior to shaping. A range of clay preparation methods can be used to purify clays, such as drying the clay, crushing, grinding and winnowing or sieving it in a dry state, or levigating, in which clay is mixed with water to separate coarser inclusions from the clay matrix (Rice, 2015, p.133). To explore such methods and how they might have been utilised in Early Iron Age Iberia, some experimental studies have been conducted (see Krueger et al., 2018, Sáez Romero et al., 2021).

Continuity in the use of clay sources by indigenous groups adopting the potter's wheel would provide important evidence for the persistence or sharing of technological knowledge between potters with different modes of production. Below I will consider this topic in more detail and discuss its implications for understanding questions surrounding identity and processes of hybridisation in the southern Iberian Early Iron Age.

\section{Postcolonial perspectives and material hybridity}

Evidence for the persistence and/or abandonment of deeprooted technological knowledge can contribute to examining questions of identity in the context of the Phoenician colonisation of the Iberian Peninsula and particularly the power dynamics between indigenous and Phoenician settlements. Studies of ancient forms of colonialism in the Mediterranean address the contribution of the "colonised" to processes of culture change under the banner of postcolonial archaeology (Gosden, 2004; Tronchetti and Van Dommelen, 2005; Hodos, 2009; Van Dommelen, 2011). Under the influence of such research, it is often considered that processes of cultural interaction taking place in eastern Mediterranean colonies in the western Mediterranean resemble a "Middle Ground" (Gosden, 2004) in which people and cultures interact and mix. Such work, in part, draws upon a set of concepts put forward by Homi Bhabha (1994) to describe the political dimensions of interaction and identification in postcolonial situations (see also Stockhammer, 2012, p.46). Bhabha utilised the concept of "hybridity" to describe the "in-betweenness" of culture, and "Third Space" as the arena where the interactions that constitute new identities take place, describing a tension between "received" tradition and its re-evaluation in the light of authorised power and privilege (Bhabha, 1994, p.3). Such concepts have been employed by postcolonial archaeologists to recognise that powerrelationships in colonial systems are not wholly asymmetrical and that identities of both "coloniser" and "colonised" are complex and in flux, constituted by people drawing upon multiple resources, ideas and practices. This is in contrast to more simplistic traditional accounts that dichotomously see the "colonised" as passive receivers of a "dominant" coloniser's material culture (Hodos, 2010). In the absence of first-hand accounts of processes of hybridisation and interaction in ancient societies, archaeologists have suggested that the terminologies of postcolonial theory of Bhabha and others can be used to describe relationships within ancient forms of colonialism, utilising artifacts and material culture as evidence of the transformed and novel identities that emerged in the Iron Age Mediterranean.

In the context of the Iberian Peninsula, for example, we find references to "hybrid" grey-ware, ceramics produced on the potter's wheel but with typological elements that are thought to originate in pre-colonial, Late Bronze Age ceramic traditions (Roos, 1982; Caro Bellido, 1989; Lorrio, 1989; Mancebo et al., 1992; Maass-Lindemann, 2000; Sanna, 2009). In particular, grey-ware was fired in reducing atmospheres which is uncommon in Phoenician ceramic production but is standard in Late Bronze Age ceramic production in southern Iberia (see also Dorado Alejos, 2019). This characteristic of grey-ware is considered by some as an intentional strategy to appeal to a new aesthetic in which indigenous preferences are adopted in Phoenician products to cater for local markets (Vallejo Sánchez, 2016). The process by which such hybrid pottery types developed is, however, still poorly understood partly due to a lack of recent typological studies and evidence from the early stages of Phoenician colonisation. Recent evidence from Castillo de Doña Blanca, which will be discussed below, provides a rare glimpse into the technological choices that underpin the production of grey-ware pottery and will therefore be used as a basis for addressing the relevance of petrographic analysis for addressing questions about material hybridity (Johnston, 2015).

Another issue is that it is not often clear exactly what is meant when the term hybridity is used to describe archaeological phenomena. Discussions are needed to take into consideration the discrepancy between the contexts of production and the context of use of objects, in which the context of production is often governed by culturally transmitted conventions and embodied skills that are for the most part reproduced unconsciously. Furthermore, although material culture appears hybrid to the eyes of archaeologists, it might not have been perceived in the same way in the past. Lastly, Bhabha's (1994) utilisation of the term addresses the political dimensions of processes of hybridisation, which translate poorly to the distant past. The remainder of this article, therefore, assesses the theoretical approaches to ceramic technology and discusses how 
notions of technological change are conflated with theories of hybridisation in the Phoenician colonial system.

\subsection{The development of "hybrid" ceramic technologies}

A petrographic and chemical study of ceramic production in the Bay of Cádiz provides insights into the coexistence of different pottery technologies in the Early Iron Age (Johnston, 2015). This has shown that separate technological traditions, relating to the production of Phoenician pottery on the one hand, and to the production of hand-made burnished ware on the other, co-existed between c. 750-550 BCE (Johnston, 2015). Phoenician pottery was produced from marl-rich clays from nearby the Phoenician settlement at Gadir. Late Bronze Age and Early Iron Age hand-made pottery, instead, was produced from clays from two distinct sources, tempered with dolerite or grog (Johnston, 2015, p.332). This shows that distinct clay selection and preparation methods corresponded to distinct fashioning methods. Johnston's (2015) research demonstrates that one of the clay sources utilised by Late Bronze Age potters is gradually abandoned during the Early Iron Age. This evidence shows that contemporary potting traditions in this region were completely distinct despite their spatial proximity, reflecting persisting technological "polarisation" (e.g., Roux et al., 2017), corresponding to processes of learning and information transmission addressed in sections 2 and 3.

Nevertheless, this study also shows that new forms of ceramics, particularly grey-ware, might have developed in the context of the Phoenician pottery workshop. Grey-ware, although later produced on the potter's wheel, was here initially hand-made. However, instead of corresponding to Late Bronze Age technologies, such ceramics were produced from clays which match the composition of the contemporary wheel-made Phoenician pottery (Johnston, 2015, p.333).

In contrast, in indigenous production centres such as Cerro de los Infantes, there might have been continuity in the use of pre-existing clay sources for the production of greyware, given that grey-ware from Morro de Mezquitilla falls into a similar geochemical grouping as Final Bronze Age pottery from this site (Dorado Alejos, 2019, pp.443-444). Also at Setefilla, there is no clear distinction between clay pastes used for the production of hand-made or wheel-made pottery, and vessel shapes originating in local Late Bronze Age and Phoenician pottery traditions are produced using either shaping method (Krueger et al., 2018).

Based on these rare studies, it seems as though the selection of clays for the production of grey-ware reflects broadly the divergence we find in the uses of clay between Phoenician and indigenous production centres. Such evidence suggests that grey-ware developed separately in different technological traditions, a point which will be further explored below.

\section{Discussion}

This article set out to evaluate the contribution of archaeometric studies to questions of social interaction and cultural transmission corresponding to the spread of the potter's wheel in the Iberian Peninsula during the Iron Age. Preliminary conclusions that can be drawn from this and areas for future research are discussed below.

The picture that emerges from the growing body of archaeometric and technological studies supports theories about the commercial strategies of Phoenician colonies, utilising locally produced ceramics for trade. Studies into the provenance of Phoenician ceramics demonstrate that the local production of pottery in and nearby the Phoenician colonies commenced rapidly, utilising clays encountered in the surroundings of such sites.

Phoenician ceramic production marks a significant departure from foregoing ceramic technologies, not only in the shaping methods employed (probably utilising stone "pivot and socket" wheels similar to those found at sites in the eastern Mediterranean), but also in the organisation of ceramic production, the labour force involved and the clay sources exploited. Archaeometric evidence from Phoenician and indigenous settlements in the Bay of Cádiz area provides a clear example of this shift by demonstrating that clay procurement and clay preparation strategies of potters utilising traditional hand-shaping methods, and those that worked with the potter's wheel, differed significantly (Johnston, 2015). Notably, evidence of the organisation of ceramic production in indigenous Iberian villages is scarce, and it is broadly assumed that domestic modes of production prevailed. Some scholars have gone as far as to suggest that such hand-made pottery traditions relate to female labour, whilst the introduction of the potter's wheel marks a shift to the production and control of ceramic manufacturing by men (Delgado Hervás and Ferrer, 2007; Padilla Fernández and Dorado Alejos, 2017). The appearance of wheel-thrown pottery alone cannot confirm such shifts in the division of labour, and we should be careful to associate specific classes of objects with specific ethnic or gender groups without substantial evidence.

Furthermore, due to the emphasis of Iron Age research on wheel-made pottery, be it for typochronological purposes or because such ceramics are seen to allude to trade and interaction, the persistence and scale of pottery production outside the workshop is unknown. Research into the chronology of wheel-made and hand-made pottery in the Iberian Peninsula has shown that the production of hand-made pottery persists alongside the production of wheel-made pottery at most sites throughout the first millennium BCE, being more prevalent in northern Iberia (de Groot and Bloxam, 2021). In order to understand the impact of the adoption of the potter's wheel across the Iberian Peninsula, and its effect on local economies and the organisation of labour, it is therefore essential to consider the organisation of the production of hand-made pottery, and how this changes through time. Archaeometric research that compares such contemporary hand-made and wheel-made pottery can provide further insights into the level of technological continuity such hand-made ceramics exhibit. 


\subsection{Hybridity and the spread of the potter's wheel}

Grey-ware provides an interesting glimpse into the development of new forms of material culture in the western Phoenician colonies. Although previous research has highlighted the "hybrid" nature of such ceramics, in the light of difficulties in establishing the nature of the social processes and political intentions underpinning the production of this material culture, "hybridity" (sensu Bhabha) might not be the most useful term to describe these processes (see section 3). It is possible that elements of distinct pottery traditions in the Bay of Cádiz transcended the boundaries of their "polarised" production strategies (see Johnston, 2015 and section 4.3), but, in the case of grey-ware ceramics, it is impossible to be certain which elements are "Phoenician" and which are "indigenous". As far as the evidence allows, most of the grey-wares' technological and stylistic characteristics could be ascribed to Phoenician ceramic production, although this changes when its production in "indigenous" workshops is considered. Even if such ceramics developed as handmade shapes, their later production on the wheel might not indicate a deliberate process of imitation of Late Bronze Age shapes and colour-schemes. Finally, considering the nature of ceramic technology, instead of adhering to fixed practices, it may be under constant negotiation due to the influence of "unpredictable circumstances, surroundings, and mix of participants" (e.g., Pauketat, 2001, p.80, my emphasis). The randomness of such factors suggests that the hybridisation we observe in the wake of ancient forms of colonialism is in fact no different from any other processes of technological change that we can trace in the archaeological record.

A final comment to make is that studies of ancient forms of colonialism and hybridisation are deeply preoccupied with questions of ethnicity. In the context of this research, it is not at all clear who worked in Early Iron Age pottery workshops. The Levantine population in the Iberian Peninsula might have been quite limited, being restricted to a relatively small group of merchant families, rather than a persistent influx of individuals from the eastern Mediterranean. It is telling that ancestry from Central and Eastern Mediterranean individuals only shows up in ancient DNA sequences from the Iberian Peninsula during the Late Iron Age (Olalde et al., 2019, p.3), suggesting that migration into Iberia from these regions was low in the Early Iron Age.

This raises several questions: firstly, who was responsible for controlling Phoenician ceramic production and the trade in goods; and, secondly, did the individuals in control identify as Phoenicians, indigenous, both or neither? Perhaps it is more helpful to speak of the rearrangement of hierarchical structures driven by Phoenician commerce, rather than ascribing ethnic categories to the inhabitants of southern Iberia. Those who controlled the production and flow of goods are likely to have benefitted most from the economic opportunities long-distance networks afforded (e.g., Delgado Hervás, 2013, pp.322-323). Instead, those who provided agricultural labour, worked in mines, and those who worked in pottery workshops, are likely to have experienced the physical impacts of the Early Iron Age economic transformations. It is therefore tempting to speculate that material culture such as grey-ware is a manifestation of the interactions taking place during the reorganisation of labour. Such processes will have affected the intergenerational transmission of pottery technologies, leading in some cases to their abandonment. In other cases, the development of new production strategies may have facilitated the collaboration between skilled and unskilled craftspeople, leading to new contexts and outcomes of production.

\section{Conclusions}

This paper has attempted to summarise and compare some initial finding from existing technological studies concerning the uses of ceramic raw materials in the first ceramic workshops in the Iberian Peninsula. This study demonstrated how evidence from archaeometric and ceramic petrographic studies can be integrated into debates surrounding cultural transmission, the development of technological knowledge, and "hybridity", in the context of the Phoenician colonisation of the Iberian Peninsula. The above interpretations should improve if evidence from future archaeometric studies is discussed comparatively.

\section{Acknowledgements}

This research was funded by the author's Leverhulme Trustfunded Early Career Fellowship project entitled "Economies of innovation: tracing the potter's wheel in Iron Age southern Europe" (ECF-2019-081). I would like to thank the organisers of the "Archaeological Approaches to the Study of the Potter's Wheel" conference and two anonymous reviewers for their helpful comments and suggestions.

\section{References}

ALBERO SANTACREU, D., 2017. Interpreting long-term use of raw materials in pottery production: A holistic perspective. Journal of Archaeological Science: Reports, 16, 505-512.

ALMAGRO GORBEA, M., 2014. Iberia: Protohistory of the Far West of Europe: from Neolithic to Roman Conquest. Burgos: Universidad de Burgos and Fundación Atapuerca.

AMADORI, M.L., DEL VAIS, C., FERMO, P., and PALLANTE, P., 2017. Archaeometric researches on the provenance of Mediterranean Archaic Phoenician and Punic pottery. Environmental Science Pollution Research, 24, 13921-13949.

AMADORI, M.L., and FABBRI, B., 1998. Produzione locale e importazioni di ceramiche fenicie da mensa (fine VIII-fine VII secola a. C.) a Toscanos (Spagna meridionale). In: R. Alaimo, C. Greco, and G. Montana, eds. Produzione e circolazione della ceramica Fenicia e Punica nel Mediterraneo. Bologna: University Press Bologna, pp. 43-56.

ARANCIBIA-ROMÁN, A., and ESCALANTE AGUILAR, M., 2006. La Málaga fenicio-púnica a la luz de los últimos hallazgos. Mainake, 28, 333-360

ARRIBAS, J., CALDERÓN, T., RUFETE, P., and FERNÁNDEZ JURADO, J., 1989. Estudio mineralógico comparativo de restos arqueológicos indígenas e importados de Tejada la Vieja (Escacena) y Huelva. In: J. Fernández Jurado, ed. Tejada la Vieja: una ciudad protohistórica. 
Huelva: Huelva Arqueológica, 9, pp. 243-258.

AUBET SEMMLER, M.E., 2008. The Phoenicians and the West: Politics, Colonies and Trade. $2^{\text {nd }}$ ed. Cambridge: Cambridge University Press.

BALDI, J., and ROUX, V., 2016. The innovation of the potter's wheel: a comparative perspective between Mesopotamia and the southern Levant. Levant, 48, 236-253.

BARTKOWIAK, M., and KRUEGER, M., 2015. Wstępne rezultaty analizy petrograficznej ceramiki ze stanowiska Setefilla (Hiszpania). Poznańskie studia nad najstarszymi dziejami Iberii, 1, 37-45.

BEHRENDT, S., and MIELKE, D.P., 2011. Provenienzuntersuchungen mittels Neutronenaktivierungsanalyse an phönizischer Keramik von der Iberischen Halbinsel und aus Marokko. Madrider Mitteilungen, 52, 139-237.

BERNAL CASASOLA, D., and SÁEZ ROMERO, A.M., 2003. Saladeros y alfares en Gadir. la perspectiva productiva de las ciudades feniciopúnicas del Extremo Occiente. In: Las ciudades fenicio-púnicas en el Mediterráneo Occidental: III Coloquio Internacional del Centro de Estudios Fenicios y Púnicos. Olmería: Universidad de Almería - Centro de Estudios Fenicios y Púnicos, pp. 315-368.

BEVAN, A., 2014. Mediterranean containerization. Current Anthropology, $55,387-418$

BHABHA, H.K., 1994. The location of culture, New York: Routledge.

CARDELL, C., RODRÍGUEZ GORDILLO, J.M., MOROTTI, M., and PÁRRAGA, M., 1999. Arqueometría de cerámicas fenicias de" Cerro del Villar"(Guadalhorce, Málaga): composición y procedencia. In: J. Capel Martínez, ed. Arqueometría y arqueología. Granada: Universidad de Granada, pp. 107-120.

CARO BELLIDO, A., 1989. Cerámica gris a torno tartesia, Universidad de Cádiz: Servicio de Publicaciones.

CARRASCO, J., PACHÓN, J., PASTOR, M., and NAVARRETE, M., 1985. Memoria preliminar de la campaña de excavaciones de 1985 en el Cerro de la Mora (Moraleda de Zafayona, Granada). Anuario arqueólogico de Andalucía, 2, 266-271.

CARRETERO, P., ARRUDA, A., CARRETERO, M., PETIT, M., GARCÍA, and RUCANDIO, M., 2008. Archaeometry of a New Punico-Turdetano Amphora Type: The Oil Amphorae from the Campiña Gaditana (Cádiz, Spain). In: J.-F. Moreau, R. Auger, J. Chabot, and A. Herzog, eds. 36 International Symposium on Archaeometry. Québec: CELAT, Université Laval, pp. 261-268.

CARRETERO POBLETE, P.A., 2007. Agricultura y Comercio PúnicoTurdetano en el Bajo Guadalquivir. El inicio de las explotaciones oleicolas peninsulares (siglos $I V-I I ~ a C$ ). BAR International Series, 1703. Oxford: Archaeopress.

CAU ONTIVEROS, M., 2007. Caracterización mineralógica y petrográfica de los materiales anfóricos. In: J. Ramon, A. Sáez, A.M. Sáez and A. Muñoz, eds. El taller alfarero tardoarcaico de Camposoto. Sevilla: Monografias de Arqueologia, 26, Junta de Andalucía, pp. 269-281.

CAU ONTIVEROS, M., ILIOPOULOS, I., and MONTANA, G., 2010. Caracterización petrográfica de cerámicas a mano ya torno del yacimiento protohistórico de la Plaza de la Catedral (Ceuta). In: F. Villada Paredes, J. Ramon Torres, and J. Suarez Padilla, eds. El asentamiento protohistorico de Ceuta: Indigenas y fenicios en la orilla Norteafricana del estrecho de Gibraltar. Ciudad Autónoma de Ceuta: Archivo General e Ceuta, pp. 449-480.

CELESTINO PÉREZ, S., and LÓPEZ-RUIZ, C., 2016. Tartessos and the Phoenicians in Iberia, Oxford: Oxford University Press.

CHOLEVA, M., 2020. Travelling with the potter's wheel in the Early Bronze Age Aegean. Annual of the British School at Athens, 2020, 1-46.

COLL CONESA, J., 2000. Aspectos de tecnología de producción de la cerámica ibérica. Saguntum: Papeles del Laboratorio de Arqueología de Valencia-Extra, 2000, 191-207.

CURIÀ BARNĖS, E., FERNÁNDEZ, A., DELGADO HERVÁS, A., and PÁRRAGA, M., 2000. La organización de la producción de cerámica en un centro colonial fenicio: el taller alfarero del siglo VI ane del Cerro del Villar (Málaga). In: M. Barthélemy, and M.E. Aubet Semmler, eds. Actas del IV Congreso Internacional de Estudios Fenicios y Púnicos: Cádiz, 2 al 6 de octubre de 1995. Cádiz: Universidad de Cádiz, Servicio de Publicaciones, pp. 1475-1485.

DE GROOT, B.G., and BLOXAM, A., 2021. Radiocarbon approaches for mapping technological change: the spread of the potter's wheel in the Iberian Peninsula, 1000-0 BCE. Journal of Archaeological Science:
Reports, 2021.

DE SOUSA, E., 2019. O comércio na costa atlântica portuguesa durante a segunda metade do $1 .{ }^{\circ}$ milénio aC. In: E. Ferrer Albelda, ed. La ruta de las Estrímnides. Navegación y conocimiento del litoral atlántico de Iberia en la Antigüedad. Alcalá de Henares: Universidad de Alcalá: Universidad de Sevilla, pp. 499-520.

DELGADO HERVÁS, A., 2011. La producción de cerámica fenicia en el extremo occidente: hornos de alfar, talleres e industrias domésticas en los enclaves coloniales de la Andalucía mediterránea (siglos VIII-VI aC). Treballs del Museu Arqueologic d'Eivissa e Formentera = Trabajos del Museo Arqueologico de Ibiza y Formentera, 2011, 9-48.

DELGADO HERVÁS, A., 2013. Households, Merchants, and Feasting: Socioeconomic Dynamics and Commoners' Agency in the Emergence of the Tartessian World (Eleventh to Eigth Centuries B.C.). In: M. Cruz Berrocal, L. García Sanjuán, and A. Gilman, eds. The Prehistory of Iberia: Debating Early Social Stratification and the State. London and New York: Routledge, 311-336.

DELGADO HERVÁS, A., and FERRER, M., 2007. Cultural contacts in colonial settings: the construction of new identities in Phoenician settlements of the Western Mediterranean. Stanford Journal of Archaeology, 5, 18-42.

DIETLER, M., and LÓPEZ-RUIZ, C., 2009. Colonial encounters in ancient Iberia: Phoenician, Greek, and indigenous relations, Chicago and London: University of Chicago Press.

DOBRES, M.-A., 1999. Technology's links and chaînes: the processual unfolding of technique and technician. In: M.-A. Dobres, and C.R. Hoffman, eds. The Social Dynamics of Technology: Practice, Politics, World Views. Washington, D.C.: Smithsonian Institution Press, pp. 124 146.

DORADO ALEJOS, A., 2019. Caracterización de las producciones cerámicas de Andalucía oriental y el sudeste de la peninsula ibérica: del bronce tardio al hierro antiguo (1550/1500-550 cal ac). Unpublished thesis $(\mathrm{PhD})$, University of Granada.

EDREIRA, M., FELIÚ, M., and VILLENA, V., 2001. Caracterización por Métodos Químico-Físicos de Cerámicas del Yacimiento de Pocito Chico. In: J. Ruiz Gil, and J. López Amador, eds. Formaciones sociales agropecuarias en la Bahía de Cádiz. Sevilla: Monografías de Arqueología, 26, Sanlúcar de Barrameda, pp. 157-176.

ESCACENACARRASCO, J.L., 1993. De la muerte de Tartesos: Evidencias en el registro poblacional. SPAL - Revista de Prehistoria y Arqueología, $2,138-218$

FANTUZZI, L., KIRIATZI, E., SÁEZ ROMERO, A.M., MÜLLER, N.S., and WILLIAMS, C.K. 2020. Punic amphorae found at Corinth: provenance analysis and implications for the study of long-distance salt fish trade in the Classical period. Archaeological and Anthropological Sciences, 12, 1-21.

FERNÁNDEZ MAROTO, D., 2013. Tornos de alfarero protohistoricos del Cerro de las Cabezas (Valdepenas, Ciudad Real) Espacio, Tiempo y Forma: Prehistoria y Arqueologia, Serie I, 297-322.

FERREIRA, L., BARROS, L., MACHADO, A., GONZALEZ, A., CASIMIRO, T., and PEREIRA, M., 2018. Spectroscopic characterization of the $8^{\text {th }}$ to $7^{\text {th }} \mathrm{BC}$ amphorae from Almaraz site, Almada, Portugal. Journal of Archaeological Science: Reports, 21, 166-174.

FERREIRA, L., DE SOUSA, E., PEREIRA, M., GUERRA, S., and MACHADO, I., 2020. An archaeometric study of the Phoenician ceramics found at the São Jorge Castle's hill in Lisbon. Ceramics International, 46, $7659-7666$.

GARCÍA FERNÁNDEZ, F.J., FERRER ALBELDA, E., ÁLVAREZMATEOS, M.P., and DURÁN-BARRANTES, M.D.L.M., 2016. Análisis de residuos orgánicos y posibles contenido en ánforas púnicas y turdetanas procedentes del Valle del Guadalquivir. Saguntum. Papeles del Laboratorio de Arqueología de Valencia, 48, 59-87.

GARCÍA VARGAS, E.A., and GARCÍA FERNÁNDEZ, F.J., 2012. Los hornos alfareros de tradición fenicia en el valle del Guadalquivir y su perduración en época romana: aspectos tecnológicos y sociales. SPAL Revista de Prehistoria y Arqueología, 21, 9-39.

GONZÁLEZ-RUIBAL, A., 2004. Facing two seas: Mediterranean and Atlantic contacts in the north-west of Iberia in the first millennium BC. Oxford Journal of Archaeology, 23, 287-317.

GONZÁLEZ-VILCHEZ, C., GARCÍA-RAMOS, G., GONZÁLEZGARCÍA, F., and PELLICER-CATALÁN, M., 1982. Cerro Macareno 
(Sevilla) Pottery: The Nature and Provenance of Amphoras and other Earthenware Pots from VIII to III Centuries B.C. In: A. Aspinall, and S. Warren, eds. Proceedings of the 22nd Symposium on Archaeometry. Bradford: Bradford University, 388-403.

GONZÁLEZ DE CANALES, F., DOMÍNGUEZ MONEDERO, A.J., LLOMPART GÓMEZ, J., MONTAÑA JUSTO, A., 2018. Un grupo nuevo de cerámica arcaica Griega ("Grupo H") fabricado en Tartessos (Huelva, España). Cuadernos de Prehistoria y Arqueología, 44, 133-143.

GONZÁLEZ DE CANALES, F., SERRANO PICARDO, L., LLOMPART GÓMEZ, J., GARCÍA FERNÁNDEZ, M., RAMÓN TORRES, J. DOMÍNGUEZ MONEDERO, A., and MONTAÑO JUSTO, A., 2017. Archaeological Finds in the Deepest Anthropogenic Stratum at 3 Concepción Street in the City of Huelva (Spain). Ancient West and East, $16,1-61$.

GONZÁLEZ PRATS, A., and PINA GOSÁLBEZ, J.A., 1983. Análisis de las pastas cerámicas de vasos hechos a torno de la fase orientalizante de Peña Negra (675-550/35 AC). Lucentum, 2, 115-145.

GOSDEN, C., 2004. Archaeology and colonialism: cultural contact from 5000 BC to the present. Cambridge: Cambridge University Press.

GOSSELAIN, O., 1992. Technology and style: potters and pottery among Bafia of Cameroon. Man, 1992, 559-586.

GUTIÉRREZ LÓPEZ, J.M., SÁEZ ROMERO, A., and REINOSO DEL RÍO, M.C., 2013. La tecnología alfarera como herramienta de análisis histórico: reflexiones sobre los denominados" prismas cerámicos". SPAL - Revista de Prehistoria y Arqueología, 22, 61-100.

HOARD, R.J., O'BRIEN, M.J., KHORASGANY, M.G., and GOPALARATNAM, V.S., 1995. A materials-science approach to understanding limestone-tempered pottery from the Midwestern United States. Journal of Archaeological Science, 22, 823-832.

HODOS, T., 2009. Colonial engagements in the global Mediterranean Iron Age. Cambridge Archaeological Journal, 19, 221.

HODOS, T., 2010. Local and global perspectives in the study of social and cultural identities. In: S. Hales, and T. Hodos, eds. Material culture social identities in the ancient world. Cambridge: Cambridge University Press, 3-31.

JIMÉNEZ AVILA, J., 2013. En torno a los tornos. A propósito de una piedra de torno de alfarero de la I Edad del Hierro conservada en la Colección de Prehistoria de la Comarca de Mérida (Badajoz). In: D. Bernal Casasola, L.C.J. Tovar, M. Bustamante-Álvarez, J.J. Díaz Rodríguez, and A.M Sáez Romero, eds. Hornos, talleres y focos de producción alfarera en Hispania: I Congreso Internacional de SECAH, Ex Officina Hispana, Cádiz 3-4 de marzo de 2011. Cádiz: Universidad de Cádiz, pp. 187-198. JOHNSTON, P.A., 2015. Pottery Production at the Phoenician Colony of El Castillo de Dona Blanca (El Puerto de Santa Maria, Spain) c. 750-550 $B C E$. Unpublished thesis $(\mathrm{PhD})$, Harvard University.

KRUEGER, M., BRANDHERM, D., KRUEGER, M., and NIEDZIELSKI, P., 2021. Archaeometric analysis of Late Bronze Age and Early Iron Age pottery from Setefilla (SW Spain). Mediterranean Archaeology and Archaeometry, 21, 21-36.

KRUEGER, M., KRUEGER, M., and JAKUBOWSKI, K., 2018. Some Remarks on the Technological Process of Tartessian Pottery. EXARC, 2018, 1-7.

LECHTMAN, H., 1977. Style in technology, some early thoughts. In: H. Lechtman, and R. Merrill, eds. Material culture: styles, organization, and dynamics of technology. St. Paul, Minnesota: West Publishers, pp. 3-20.

LIVINGSTONE SMITH, A., 2000. Processing clay for pottery in northern Cameroon: Social and technical requirements. Archaeometry, 42, 21-42.

LORRIO, A.J., 1989. Cerámica gris orientalizante de la necrópolis de Medellín (Badajoz). Zephyrus, 41-42, 283-314.

LORRIO, A.J., 2014. The Celtic peoples. In: M. Almagro Gorbea, ed. Iberia. Protohistory of the Far West of Europe: From Neolithic to Roman Conquest. Burgos: Universidad de Burgos \& Fundación Atapuerca.

MAASS-LINDEMANN, G., 2000. El yacimiento fenicio del Alarcón y la cuestión de la cerámica gris. In: Fenicios y territorio: actas del II Seminario Internacional sobre Temas Fenicios, Guardamar del Segura, 9-11 de abril de 1999. Alicante: Instituto Alicantino de Cultura Juan GilAlbert, pp. 151-168.

MANCEBO, J., DE LA BANDERA, M.L., and GARCÍA, J.M., 1992. La cerámica gris a torno del yacimiento orientalizante de Montemolín (Sevilla). Trabajos de Prehistoria, 49, 277-293.
MANNING, J.G., 2018. The open sea: the economic life of the ancient Mediterranean world from the Iron Age to the rise of Rome, Princeton and Oxford: Princeton University Press.

MENDOZA, A., MOLINA, F., ARTEAGA, O., AGUAYO, P., and SAEZ, L., 1981. Cerro de los Infantes (Pinos Puente, Provinz Granada). Ein Beitrag zur Bronze und Eisenzeit in Oberandalusien in Helmut Schlunk zum 75. Geburtstag. Madrider Mitteilungen, 22, 171-210.

MIELKE, D.P., 2015. Between transfer and interaction: Phoenician pottery technology on the Iberian Peninsula. In: W. Gauss, G. Klebinder-Gauss, and C. von Ruden, eds. The transmission of technical knowledge in the production of ancient Mediterranean pottery. Vienna: Österreichisches Archäologisches Institut, pp. 257-276.

MIELKE, D.P., and TORRES ORTIZ, M., 2012. Technologietransfer undentwicklung auf der iberischen Halbinsel im Rahmen der orientalischphönizischen Kulturkontakte. In: A. Kern, J.K. Koch, I. Balzer, J. Fries-Knoblach, K. Kowarik, C. Later, P.C. Ramsl, P. Trebsche, and J. Wiethold, eds. Technologieentwicklung und-transfer in der Hallstattund Latènezeit. Beiträge zur Internationalen Tagung der AG Eisenzeit und des Naturhistorischen Museums Wien, Prähistorische AbteilungHallstatt. Langenweißbach: Beier \& Beran, pp. 263-286.

MIGUEL GASCÓN, E., and BUXEDA I GARRIGÓS, J., 2013. Characterisation of possible Phoenician pottery production of Tyre. Applied Clay Science, 82, 79-85.

MIGUEL GASCÓN, E., BUXEDA I GARRIGÓS, J., and DAY, P.M., 2015. Central Mediterranean Phoenician pottery imports in the Northeastern Iberian Peninsula. Journal of Archaeological Science: Reports, 3, 237 246.

MILLÁN, A., ARRIBAS, J., BENITEZ, P., CALDERÓN, T., and RUFETE, P., 1990. Caracterización mineralógica de cerámicas de filiacion fenicia, griega y turdetana de Huelva. Huelva Arqueologica, 12, 401-446.

MOLINOS, M., RÍSQUEZ, C., SERRANO, J., and MONTILLA, S., 1994. Un problema de fronteras en la periferia de Tartessos: Las Calañas de Marmolejo (Jaén), Jaén: Universidad de Jaén.

MORENO MEGÍAS, V., GARCÍA FERNÁNDEZ, F.J., FRAGNOLI, P., and STERBA, J.H., 2020. Petrographic and neutron activation analysis of Late Iron Age amphorae from the south western Iberian Peninsula. Journal of Archaeological Science: Reports, 34, 102598.

MÜlLER, N.S., KILIKOGLOU, V., DAY, P.M., and VEKINIS, G., 2014. Thermal shock resistance of tempered archaeological ceramics. In: M. Martinon-Torres, ed. Craft science: International perspectives on archaeological ceramics. Doha, Qatar: UCL Qatar Series in Archaeological and Cultural Heritag. Bloomsbury Qatar Foundation, pp. 263-270.

NIJBOER, A.J., and VAN DER PLICHT, J., 2006. An interpretation of the radiocarbon determinations of the oldest indigenous-Phoenician stratum thus far, excavated at Huelva, Tartessos (south-west Spain). BABesch, 81, 31-36.

OLALDE, I., MALLICK, S., PATTERSON, N., ROHLAND, N., VILLALBA-MOUCO, V., SILVA, M., DULIAS, K., EDWARDS, C.J., GANDINI, F., and PALA, M. 2019. The genomic history of the Iberian Peninsula over the past 8000 years. Science, 363, 1230-1234.

PADILLA FERNÁNDEZ, J.J., and DORADO ALEJOS, A., 2017. Lo que la cerámica esconde: continuidad y cambio social a finales del Bronce y comienzos de la Edad del Hierro en el castro de las Cogotas (Cardeñosa, Ávila). Complutum, 28, 87-117.

PAUKETAT, T.R. 2001. Practice and history in archaeology: An emerging paradigm. Journal of Anthropological Theory, 1, 73-98.

PETIT-DOMÍNGUEZ, M.D., GARCÍA-GIMÉNEZ, R., and RUCANDIO, M.I., 2003. Chemical characterization of Iberian amphorae and tannin determination as indicative of amphora contents. Microchimica Acta, 141, 63-68.

PRINGLE, S., 1998. The petrology of the archaic punic plates from Toscanos, Spain. The Old Potter's Almanack, 6, 2-7.

QUINN, P.S., 2013. Ceramic petrography: The interpretation of archaeological pottery related artefacts in thin section, Oxford: Archaeopress.

RAFEL FONTANALS, N., 2012. La Cuenca minera del Baix Priorat (Tarragona): explotación y distribución en época colonial, recursos locales versus recursos alóctonos. Cuadernos de Arqueología Mediterránea, 2012, 71-86.

RAMÓN TORRES, J., SÁEZ ROMERO, A.M., SÁEZ ROMERO, A., 
and MUNOZ, A., 2007. El taller alfarero tardoarcaico de Camposoto, San Fernando, Cádiz., Sevilla: Monografías de Arqueología, Junta de Andalucía.

RICE, P.M. 2015. Pottery analysis: a sourcebook. Chicago: University of Chicago Press.

ROOS, A.-M., 1982. Acerca de la antigua cerámica gris a torno en la Península Ibérica. Empúries: revista de món clàssic $i$ antiguitat tardana, 1982, 43-70.

ROUX, V., 2019. Ceramics and society: a technological approach to archaeological assemblages. Springer.

ROUX, V., BRIL, B., CAULIEZ, J., GOUJON, A.-L., LARA, C., MANEN, C., DE SAULIEU, G., and ZANGATO, E., 2017. Persisting technological boundaries: Social interactions, cognitive correlations and polarization. Journal of Anthropological Archaeology, 48, 320-335.

ROUX, V., and COURTY, M.-A., 1998. Identification of Wheel-fashioning Methods: Technological Analysis of $4^{\text {th }}-3^{\text {rd }}$ Millennium BC Oriental Ceramics. Journal of Archaeological Science, 25, 747-763.

RUIZ, T.C., SANJUÁN, L.G., PÉREZ, V.H., RAMÍREZ, J.M.M., DEL RÍO, Á.P., and TAYLOR, R., 2006. La arqueometría de materiales cerámicos: una evaluación de la experiencia andaluza. Trabajos de Prehistoria, 63, 9-35.

SÁEZ ROMERO, A.M., 2008. La producción cerámica en Gadir en época tardopúnica (siglos-III/-I), Cádiz: BAR International Series, S1812, Universidad de Cádiz.

SÁEZ ROMERO, A.M., 2014. Fish processing and salted-fish trade in the Punic West: new archaeological data and historical evolution. In: E. Botte, and V. Leicht, eds. Fish and Ships: Production et commerce des salsamenta durant l'Antiquité. Aix-en-Provence: Centre Camille Jullian, pp. $159-174$.

SÁEZ ROMERO, A.M., BELIZÓN ARAGÓN, R., and ALBURQUERQUE, P., 2021. Throwing Punic Amphorae: An Archaeological and Experimental Approach to the use of the Potter's Wheel in southern Iberia during the
Iron Age. EXARC, 2021, 1-26.

SÁEZ ROMERO, A.M., MONTERO FERNÁNDEZ, R., and TOBOSO SUÁREZ, E.J., 2004. Un antecedente centro-mediterráneo al complejo alfarero púnico de Torre Alta (San Fernando, Cádiz). In: A.M. Niveau de Villedary y Mariñas, ed. Las industrias alfareras y conserveras feniciopúnicas de la Bahía de Cádiz. Córdoba: Publicaciones Obra Social y Cultural CajaSur, pp. 201-236.

SANNA, C.J.A.Y.T., 2009. La cerámica gris orientalizante entre tradición e innovación: el caso de Ronda la Vieja (Acinipo)(Ronda, Málaga). Arqueología y Territorio, 6, 151-164.

SILLAR, B., and TITE, M.S., 2000. The challenge of "technological choices' for materials science approaches in archaeology. Archaeometry, $42,2-20$.

SINOPOLI, C.M., 1991. Approaches to archaeological ceramics, Springer. STOCKHAMMER, P.W., 2012. Conceptualizing cultural hybridization in archaeology. In: P.W. Stockhammer, ed. Conceptualizing Cultural Hybridization. A Transdisciplinary Approach. Berlin, Heidelberg: Springer, pp. 43-58.

TITE, M., and MANIATIS, Y., 1975. Scanning Electron Microscope of Fired Calcareous Clays. Transactions of the British Ceramics Society, 74, $19-22$.

TORRES ORTIZ, M., 2014. Taršiš, Tartessos, Turdetania. In: M. AlmagroGorbea, ed. Iberia. Protohistory of the Far West of Europe: From Neolithic to Roman Conquest. Burgos: Universidad de Burgos, pp. 251-283.

TRONCHETTI, C., and VAN DOMMELEN, P., 2005. Entangled objects and hybrid practices: colonial contacts and elite connections at Monte Prama, Sardinia. Journal of Mediterranean Archaeology, 18, 183.

VALLEJO SÁNCHEZ, J.I., 2016. Las cerámicas grises orientalizantes en la Península Ibérica. Unpublished thesis $(\mathrm{PhD})$, Universidad de Cádiz.

VAN DOMMELEN, P., 2011. Postcolonial archaeologies between discourse and practice. World archaeology, 43, 1-6. 